Institute of $\mathbf{F}_{\text {ood and }} \mathbf{A}_{\text {gricultural }} \mathbf{S}_{\text {ciences }}$

\title{
Pea Leafminer, Liriomyza huidobrensis (Blanchard) (Insecta: Diptera: Agromyzidae) ${ }^{1}$
}

Gary J. Steck ${ }^{2}$

\section{Introduction}

Liriomyza huidobrensis (Blanchard), the pea leafminer, is a highly polyphagous leaf miner capable of inflicting severe damage to crops. Affected crops include field- and glasshouse-grown vegetables and flowers. The pea leaf miner apparently originated in South America and has spread to other continents where established populations are growing ever more difficult to control. For example, in the Salinas Valley (Monterey Co., CA), Chaney (1995) reported that "This insect has gone from a sporadic fall pest, relatively easily controlled, to a pest throughout most of the vegetable-growing season that is essentially not able to be controlled in many crops." This is at least partly due to a shift in the pea leafminer's susceptibility to insecticides. Changes in tillage practices, especially reduced tillage on semi-permanent beds, may also be contributing to the problem. Lettuce is the worst affected crop, but nearly all of the fresh vegetables grown in the Salinas Valley are hosts for this leaf miner. Liriomyza huidobrensis has been recorded from Florida (Poe and Montz 1981; CABI/EPPO 1992), but apparently a viable population has not been established.
Larva-infested produce and cut flowers have been intercepted many times at Florida ports of entry.

\section{Distribution}

L. huidobrensis is apparently indigenous to cooler, mostly highland areas of Latin America (Spencer 1992). In South America, it is known from Argentina, Brazil, Chile including Juan Fernandez Island, Colombia, Peru, Venezuela; in Central America: Belize, Costa Rica, El Salvador, Guatemala, Honduras, Nicaragua, Panama; in the Caribbean: Dominican Republic, Guadeloupe ("introduced but not established?" [Martinez et al. 1993]); in North America: California (probably in all southern counties and along the coast and inland valleys at least as far north as Placer Co. [Spencer 1981]; a major pest in Salinas Valley of Monterey Co.); Hawaii; Europe: Belgium, Netherlands, UK.; Middle East: Israel.

\section{Description}

Agromyzid flies of the genus Liriomyza in Florida are small (1.5 to $2.0 \mathrm{~mm}$ long), mostly shiny black except for yellow on the scutellum, sides of

1. This document is EENY-111 (originally published as DPI Entomology Circular No. 378), one of a series of Featured Creatures from the Entomology and Nematology Department, Florida Cooperative Extension Service, Institute of Food and Agricultural Sciences, University of Florida. Published: August 1999. This document is also available on Featured Creatures Website at http://creatures.ifas.ufl.edu. Please visit the EDIS Website at http://edis.ifas.ufl.edu. Additional information on these organisms, including many color photographs, is available at the Entomology and Nematology Department website at http://entnemdept.ifas.ufl.edu/.

2. Gary J. Steck, Florida Department of Agriculture and Consumer Services, Division of Plant Industry, Gainesville, FL.

The Institute of Food and Agricultural Sciences is an equal opportunity/affirmative action employer authorized to provide research, educational information and other services only to individuals and institutions that function without regard to race, color, sex, age, handicap, or national origin. For information on obtaining other extension publications, contact your county Cooperative Extension Service office. Florida Cooperative Extension Service/Institute of Food and Agricultural Sciences/University of Florida/Christine Taylor Waddill, Dean. 
thorax, and middle portion of head; two pairs of reclinate orbital setae; and costal vein extending to M1+2. Liriomyza huidobrensis is distinguished from other pest species of Liriomyza in Florida, particularly L. sativae Blanchard and L. trifolii (Burgess) that share many of the same host plants, by its larger body size and overall dark color; larger discal cell and relatively short distal section of vein M3+4; the darkened femora (yellow in sativae and trifolii); and the male genitalia (see Spencer 1973). Larvae can be separated by the posterior spiracles: larvae of L. huidobrensis have six to nine bulbs, while those of $L$. sativae and $L$. trifolii have only three bulbs. Further, L. huidobrensis larvae frequently mine along the midribs of leaves, and late instar larvae are almost always found mining the lower surfaces of leaves or within petioles. This mining behavior is distinctly different from the serpentine mines of $L$. sativae and L. trifolii on upper leaf surfaces.

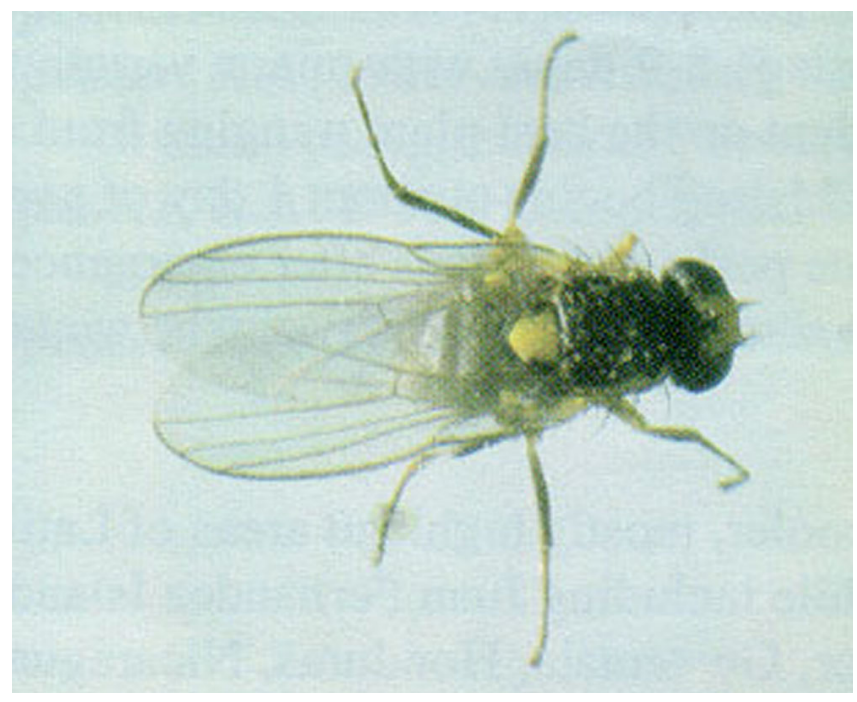

Figure 1. Adult pea leafminer, Liriomyza huidobrensis (Blanchard). Credits: J. Lotz, Division of Plant Industry

\section{Biology}

According to a study by Parrella and Bethke (1984) conducted under greenhouse conditions at 27 degrees $\mathrm{C}$, the egg stage lasts three days, the larval feeding stage about three to five days, and the pupal stage eight to nine days, with minor variation depending on host plant. Successful emergence to the adult stage is highly dependent on the host plant, ranging from a low of 36 percent for leaf miners reared on chrysanthemum to 74 percent on peas. Mating begins at about one day after adult emergence.
A single mating is sufficient to fertilize all eggs laid (Parrella 1987). Oviposition rate peaks at four to eight days after emergence. Adults live only about 12 to 14 days. Generation time in California was 17 to 30 days in summer and 50 to 65 days in the winter (Lange et al. 1957).

\section{Hosts}

This is a highly polyphagous species. Crop and ornamental host plants include (*indicates crops in which serious economic loss was noted [Spencer 1973, 1990]):

- Alstroemeriaceae: Alstroemeria (larvae unable to complete development);

-Apiaceae: Apium graveolens (celery);

- Asteraceae: Galinsoga, Gazania, Inuleae, *Lactuca sativa L. (garden lettuce), Pterocaulon, Sonchus, Tagetes;

- Brassicaceae: Brassica oleracea L. (broccoli, cauliflower);

- Caryophyllaceae: Gypsophila (baby's breath), Dianthus caryophyllus L. (carnation);

- Chenopodiaceae: *Beta vulgaris L. (beet, red chard), *Spinacia oleraceae L. (spinach);

- Cucurbitaceae: Cucumis melo L. (melon);

- Leguminosae: Lathyrus odoratus L. (sweet pea), Medicago, Melilotus, *Pisum sativum L. (garden pea), *Vicia faba L. (broad bean);

- Liliaceae: Allium cepa L. (onion, *Allium sativum L. (garlic);

- Linaceae: Linum usitatissimum L. (flax);

- Oxalidaceae: Oxalis;

- Polemoniaceae: Phlox;

- Solanaceae: *Capsicum annuum L. (pepper), Datura, Lycopersicon esculentum Miller (tomato), Petunia, Solanum tuberosum L. (potato); 
- Tropaeolaceae: Tropaeolum majus L. (nasturtium);

\section{- Violaceae: Viola}

\section{Mites and Punctures}

On foliage, mines occur on lower leaf surfaces (spongy mesophyll) and usually are associated with the midrib and lateral veins. Frass is deposited in a thin, broken to continuous line down the middle of the mine. The placement of mines on the leaf underside, the association with leaf veins, and frass deposition pattern of L. huidobrensis larvae are distinctive and distinguish them from those of other species; however, this pattern may be obscured when many larvae feed together on the same leaf (Spencer 1973). A mine usually begins on the upper leaf surface and moves to the lower surface after a few millimeters of feeding by the larva (Parrella and Bethke 1984). Flies puncture leaves for both feeding and oviposition; punctures may be numerous enough to greatly reduce photosynthesis and may kill young plants. Unsightly mines and punctures further reduce the value of ornamental plants.

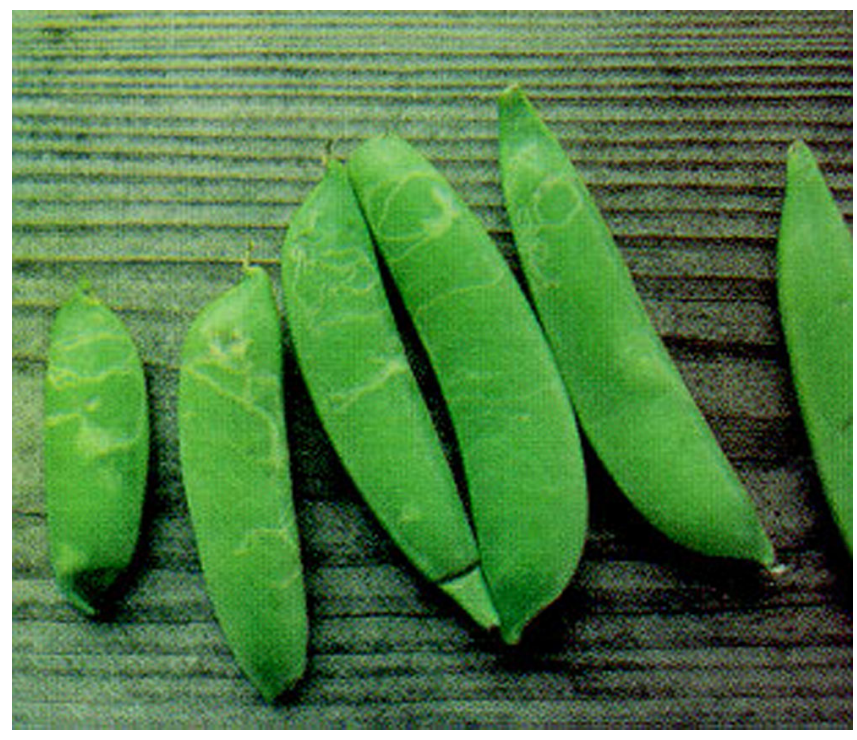

Figure 2. Typical mines on sugar snap beans caused by the pea leafminer, Liriomyza huidobrensis (Blanchard). Credits: J. Lotz, Division of Plant Industry

\section{Detection of $L$. huidobrensis in Florida}

There is only one field record of L. huidobrensis in Florida. Poe and Montz (1981) reported results of

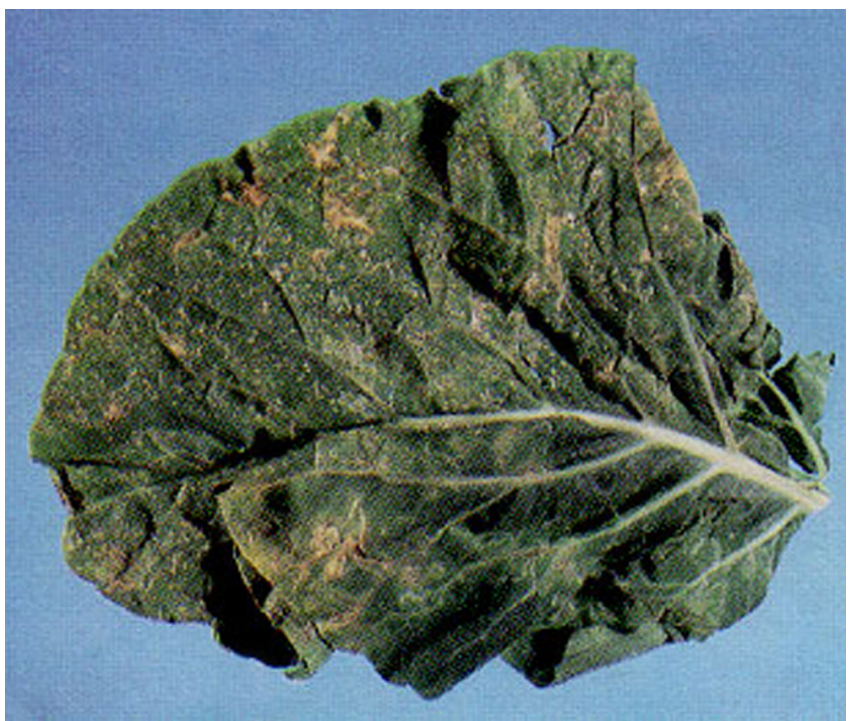

Figure 3. Feeding and oviposition punctures on cauliflower leaves by the pea leafminer, Liriomyza huidobrensis (Blanchard). Credits: J. Lotz, Division of Plant Industry

a survey for leaf miners in the USA, in which six Florida samples were submitted. Samples of flies reared from a field of Gypsophila in Lee Co. included adults of $L$. huidobrensis. However, unpublished information indicates that this was an isolated introduction, and the population did not persist. The infestation probably originated on nursery stock received from an infested area of California. The first pea leaf miner was detected in February of 1981 and only a few flies were collected between then and May 1981, at which time the crop was destroyed. The same site was resampled weekly from September 1981 to May 1982 and no further L. huidobrensis were detected (Dr. J.F. Price, IFAS- GCREC, Bradenton, personal communication). A second published report (EPPO 1992) states that L. huidobrensis occurs in glasshouses in Florida; this is probably an erroneous report based on a misreading of Poe and Montz (1981). There has not been a documented field infestation of L. huidobrensis in Florida since 1981, and to our knowledge it does not occur here. Live larvae continue to enter Florida on various hosts imported from infested areas. Possibly the climate in Florida is not amenable to year-round viability of pea leaf miner populations. However, the range of ambient and glasshouse conditions tolerated by $L$. huidobrensis has not been established, and it cannot be presumed that it will not establish under any Florida conditions. 


\section{Regulatory Action}

State regulatory agencies are responsible for inspecting imported produce, nursery stock and horticultural products. When damaged or infested plant material is detected, the associated pest species are identified, and appropriate quarantine action is undertaken if necessary. Likely sources of $L$. huidobrensis are leafy vegetables and cut flowers and nursery stock of carnation, baby's breath, and chrysanthemum from California, Hawaii, and South and Central American countries. Surveys are also underway in nursery and natural areas of Florida to confirm that it does not exist in the state. Additional information on the natural distribution and biological investigations into the basic biology of $L$. huidobrensis are needed especially as they relate to climatic requirements and Florida field, nursery, and glasshouse conditions.

\section{Selected References}

CABI/EPPO. 1992. Data sheets on quarantine pests: Liromyza huidobrensis, pp. 194- 198. In Quarantine pests for Europe. CAB International, Wallingford, Oxon, UK. 1032 p.

Capinera, J.L. 2001. Handbook of Vegetable Pests. Academic Press, San Diego. 729pp

Chaney, W.E. 1995. The pea leaf miner as a pest of vegetable crops. Monterey Co. Extension Office. Crop Notes (October): 4.

Lange, W.H., A.A. Gricarick, and E.C. Carlson. 1957. Serpentine leafminer damage. California Agriculture 11: 3-5.

Martinez, M., J. Etienne, A. Abud-Antun, and M. Reyes. 1993. Les Agromyzidae de la Republique Dominicaine (Diptera). Bulletin de la Societe entomologique de France 98: 165-179.

Parrella, M.P., and J.A. Bethke. 1984. Biological studies of Liriomyza huidobrensis (Diptera:

Agromyzidae) on chrysanthemum, aster, and pea. Journal of Economic Entomology 77: 342-345.

Parrella, J. 1987. Biology of Liriomyza. Annual Review of Entomology 32: 201-204.
Poe, S.L., and J.K. Montz. 1981. Preliminary results of a leaf miner species survey, pp. 24-34. In D.J. Schuster (ed.), Proceedings, IFAS-Industry conference on biology and control of Liriomyza leafminers. Lake Buena Vista, FL, November 3-4, 1981.

Spencer, K.A. 1973. Agromyzidae (Diptera) of economic importance. Dr. W. Junk B.V., The Hague. $418 \mathrm{p}$.

Spencer, K.A. 1981. A revisionary study of the leaf-mining flies (Agromyzidae) of California. University of California, Division of Agricultural Science. Special Publication 3273: 1-489.

Spencer, K.A. 1990. Host specialization in the world Agromyzidae (Diptera). Kluwer Academic Publishers, Dordrecht. 444p.

Spencer, K.A. 1992. Flycatcher: Memoirs of an amateur entomologist. SPB Academic Publishing, The Hague. 414 p. 